\title{
Self learning mode of flash animation course under open studio mode
}

\author{
Zhang $\operatorname{Min}^{1, *}$ \\ ${ }^{1}$ Art College of Binzhou University, Binzhou, Shandong 256603
}

\begin{abstract}
In order to further develop the self-learning mode of flash animation course under the open studio mode, it is necessary to reform the courses. Under the open studio mode, the reform of self-learning mode of flash animation course needs to be carried out under the premise of a comprehensive understanding of the purpose and goal of education. Flash animation course, as a course with strong application and operation, focuses on training students' practical design and operation ability. It is a course suitable for teachers to guide students' learning process. Under the open studio mode, the reform of self-learning mode of flash animation course must put forward higher requirements for teachers and learners in order to promote the development of education.
\end{abstract}

\section{Introduction}

Flash animation course is one of the main courses of digital media art major. It plays an important role in the professional training of digital media art specialty. It has laid a certain foundation of software operation and animation production skills for the post professional courses. It aims to cultivate students' ability to use Flash software to develop and produce animation works with certain practical value, such as story animation, e-card, simple network animation, etc.; guide students to analyze excellent flash animation cases, cultivate students' creative consciousness and imagination ability, master flash animation production methods and performance skills, and improve animation design skills and appreciation ability. Innovation is the soul of design. Teachers should constantly stimulate students' creativity and imagination in the course, and show it through software production. Therefore, the cultivation of talents in the process of teaching needs innovation. At present, enterprises want to shorten the training cycle and reduce the training cost of the required talents. Enterprises need experienced, innovative and project development staff. In the teaching process of self-learning mode of flash animation course under the open studio mode, it not only strengthens the cultivation of professional skills, but also improves the students' strong organizational ability and communication ability; It also cultivates students' comprehensive ability of skill innovation consciousness, speech ability and team spirit well trained and applied talents. However, there are still some deficiencies in the teaching of this mode, which can not let students form independent animation innovation, ignore the ability of creative skills, and do not pay attention to the cultivation of students' knowledge ability. Therefore, in this paper, combined with the needs of the market and enterprises, the cultivation of students' skills, in order to comprehensively optimize the teaching, teaching and assessment methods of flash animation course, this should be the main goal of the course.

\section{Self learning mode of flash animation course under open studio mode}

\section{1 concept of independent learning mode of flash animation course under the open studio mode}

The self-study mode of flash animation course under the open studio mode mainly includes the following course contents: the components of the open laboratory and the open experimental content. This is reflected in the experimental scheme of the course, which is completely open outside the course. The open laboratory carries out corresponding experiments according to the requirements of students. After the course, students can carry out more in-depth experiments according to their own interests. In addition, the open studio also allows students to use experimental equipment and studio facilities for experiments outside the teaching plan. It can be designed and integrated on the basis of content research, including participation in experimental activities. Open studio is a student-centered mode, which gives students maximum freedom, encourages personal development and innovation. Objective to meet the requirements of cultivating first-class talents, and to create conditions and space for cultivating high-quality practical talents, and to transform to research-oriented on the basis of "open"

*Email: zhangmin6270@163.com 
mode. In addition, in the autonomous learning mode, students teach flash animation courses in the open mode based on experimental courses. Students can make full use of the resources of the autonomous learning mode. In the third mode, students will understand and absorb the experimental content, actively think about the experiment and solve problems, and encourage students to perform independently in the experiment. The self-study mode of flash animation course under the open studio mode provides a learning environment of audio-visual combination for students, so that students can carry out specific experiments in a short time, and cultivate their ability to analyze and solve problems independently. The studio uses audio-visual materials to explain the experience intuitively in a short time. The whole teaching process aims to improve classroom efficiency and stimulate students' enthusiasm for autonomous learning. In the classroom, teachers encourage students to think independently, solve problems and do experiments. Teachers from teaching to teaching, from lecture to inspiration, cultivate students' ability to analyze and solve problems. At the same time, this teaching method promotes and promotes the communication between students.

\section{The teaching system of flash animation course autonomous learning mode under the open studio mode}

\subsection{Open studio mode flash animation course for students}

To improve the quality and efficiency of self-taught flash animation course under the open studio mode, to achieve this, we should first improve the status of flash animation course in the open studio mode, rather than put it into the category of theoretical education. In this way, students can truly realize the practical significance of open studio. The experimental part is separated from the theoretical course, and a series of self-study courses are set up in the open studio of flash animation course, which is suitable for the students of flash animation course. Teachers and schools will establish a separate studio to set up experimental projects and experimental studio courses. After the completion of a separate course, students will be provided with a special teaching material of flash animation of open studio. According to a series of self-learning courses of flash animation course under the open studio mode, the teaching content of the course is to provide practical methods and process knowledge information. The knowledge preparation and understanding of students in the studio will directly affect their education. The school reformed the existing teaching materials to adapt to the new teaching system and content. These textbooks teach the theoretical content and practical method content of traditional flash animation course, such as the theoretical knowledge related to studio autonomous learning mode, and bring it into the scope of educational research and education reform. The latter results are supplemented by a large number of complex research projects and experiments.

\subsection{Cultivate students' practical ability}

In the open studio mode, under the flash animation course independent learning mode, the students' flash animation course is cultivated and the practical ability is improved. Through the analysis of excellent animation design cases, the students can understand the flash animation production process, analyze the topic selection of thematic animation production, so that students can be inspired in the excellent cases, and improve their own appreciation ability and aesthetic quality. Based on the principle of step-by-step learning, flash animation course in autonomous learning mode includes educational content based on integrated design and practical content based on personalized research. Under the open studio mode, the self-learning mode of flash animation course includes four levels of educational content, including basic experiment, development pilot project, design of flash animation course and single research pilot project. It has widened students' vision, stimulated their innovative thinking, and provided a variety of development directions for students. The main courses of digital media art major of flash animation cultivate a solid foundation of digital media technology application and art theory, master the application principle, basic knowledge and skills of digital technology in the field of film and television art and network multimedia art, and obtain systematic digital art creation training, and be able to use advanced digital media technology to carry out digital It is a compound senior professional in film and television program production, $\mathrm{CG}$ creation and network multimedia art design.

\subsection{Create a perfect teaching environment}

Under the open studio mode, the teaching of flash animation course independent learning mode makes students separate from the course content explained by teachers. Students can learn independently according to the relevant information of studio courses. Teachers provide teaching materials for students to learn self-learning. At the same time, the video course provided by teachers helps students understand how to carry out effective autonomous learning in the studio. Teachers have produced more than 140 video materials for the practical content. These courseware design is simple and thin, and has the characteristics of vision, hearing, image, sound and text It can not only help students understand practical projects in a short period of time, but also improve classroom efficiency and stimulate students' enthusiasm for autonomous learning. At the same time, by reducing the improper use of the project and the loss of experimental materials, the project can significantly improve the efficiency. Under the open studio mode, the self-learning mode of flash animation course has established a huge pre research evaluation question bank for each teaching project. The pre research evaluation question is a combination of teaching methods 
and other theoretical knowledge and practical skills, and students use network software to conduct examination management test and training evaluation. The studio has a server room, which is open all day from Monday to Sunday. It is equipped with special software to manage the computer room. The whole use process and teaching process of students can be recorded and counted.

\subsection{Open laboratory network management for students}

Under the open studio mode, the effective management of flash animation course autonomous learning mode needs a mature education information management network platform. The main contents of the platform are: training subsystem of self-study mode under open learning mode; management subsystem of studio training support subsystem. On the portal website, the teacher has prepared all the materials and learning materials for this practice activity. All the materials of the school, the video course of the practice course, can be completed online or by downloading. In addition, it is also convenient to refer to the studio introduction, course introduction, online appointment course selection, online pre assessment, real-time use suggestions, course arrangement and other functions. Using the open studio autonomous learning management subsystem to learn flash animation course, we can practice in the classroom and outside the course, and the system can effectively manage the accumulated class hours. Open studio autonomous learning mode supports open subsystem, which provides powerful information management such as classroom management software and control system, real-time online management of teachers and students. The fully networked information exchange and management system, proposition design and entity project design make it possible to implement the self-learning mode of flash animation course under the open studio mode.

\section{Practice analysis of self learning mode of flash animation course under open studio mode}

\subsection{Management system of independent learning mode of flash animation course under open studio mode}

Whether the studio has effective management and teaching ability restricts the efficiency of self-learning mode of flash animation course under the open studio mode. The studio should make the development plan and rules, and establish the working files of the studio. Studio is an important practice platform for learning innovation and business incubation, and students are the main body of studio courses. The concept and management of open studio should follow the teaching principle of student-centered and teacher-led, so that teachers can fully participate and empower them. The dynamic nature of experimental training makes students become the participants of the project, realizes the organic unity of experimental training and social practice, and effectively develops students' independent innovation potential.

\subsection{Project course of flash animation course self learning mode under open studio mode}

Under the open studio mode, teachers play an important role in the development, improvement and implementation of the project course of flash animation course. Integrate curriculum knowledge into the project, optimize the operation of pilot projects, carry out pilot projects, encourage the study of creative design, consolidate professional ability, and pay attention to improve the comprehensive quality of students. Under the open studio mode, the self-learning mode of flash animation course always gives students an independent scope of action, expands personal knowledge content, and combines with the actual case design project, applies the skills and forms of creative design learned in it.

\subsection{Practice and innovation of independent learning mode of flash animation course under open studio mode}

Under the open studio mode, the studio in the self-learning mode of flash animation course is similar to a group or an organization. The relationship between teachers and students is designed with the help of groups or teams. The dynamic relationship between teachers and students promotes regular cooperation. In order to train the team, we introduce innovative practical activities that can play a role in running in team cooperation, such as information technology innovation competition, cultural and creative design competition, college students' advertising design competition, etc. the instructor helps the team members to enhance each other's advantages and disadvantages. Student group cooperation promotes the team cooperation among students, deepens the understanding of the theory, and makes the experiment possible. Through participating in the real competition of the actual project, the students can cultivate their creativity and learn from other people's strengths under autonomous learning, and finally achieve the goal of collaborative innovation.

\subsection{Multi party cooperation of independent learning mode of flash animation course under open studio mode}

The entity project of design practice is an important measure to improve the feasibility of self-learning mode of flash animation course under the open studio mode. On the one hand, we can make full use of the studio's advantages in education base and innovative talents, and at the same time undertake the necessary teaching tasks. While completing the necessary teaching tasks, we can initiate the provision of social services to promote the construction and development of local economy; on the other hand, schools, enterprises, public organizations and research institutions jointly organize the continuous 
development of new technologies, new methods and new tools The seminar has a practical framework for technology transfer outside the school, carrying out bilateral or multilateral cooperation, clarifying the division of labor, and participating in the management and teaching process of the studio together. The open studio has also become a link between students and the society, combining the educational resources of the school with the joint efforts of the society, and integrating the innovation practice platform into the innovation and entrepreneurship incubation platform.

\section{The assessment mode of flash animation course autonomous learning mode under the open studio mode}

\subsection{Preview and spot check}

First of all, the studio meets the school attendance requirements, and students who do not meet the attendance requirements will be disqualified. In addition, the studio requires students to conduct pre assessment before participating in the experimental courses, and to conduct evaluation on the education network management platform. The preview can only be conducted before the experimental course is started. Students who fail to pass the prediction can take the test again after 12 hours. If you fail to pass the pre evaluation in the experimental teaching, you will not get a score in this experiment. The teaching information management platform adds the function of random sampling before the experimental work, which includes a list of students selected according to a certain proportion. According to the list, teachers conduct on-the-spot inspection of students' homework. Through the process of question and answer, teachers can not only test the students' understanding of the experimental project, but also practice the key and difficult points of the experiment by asking questions.

\subsection{Combination of learning report and final evaluation}

In the new training mode, the score of each test item is controlled by the combination of practical operation and laboratory report. The final evaluation is automatically evaluated by computer, and the test report is completed according to the test operation. For the test mode, the following evaluation criteria are determined: (1) understand the principle of experimental design and flash animation design; (2) whether the flash animation design practice is correct; (3) collect and sort out the experimental data. At the same time, according to different experimental items, the index value will be different.

\subsection{Evaluation of competition and innovation in learning mode}

It can better promote students' innovative thinking, and can also improve software operation ability and performance ability through practice. Each year, the studio can reward the students who have achieved results in various competitions, and provide them with experimental courses, free from examination, and be rated as excellent; for the competition, students who meet certain conditions can be exempted from experimental classes, and their scores are evaluated as excellent. Teachers encourage students to use different methods to complete their assignments in the experimental class which emphasizes practical ability and overall design of experiments. For the design works involving innovative thinking, the students can get high marks in the ordinary performance of the course after the examination and approval of the instructor. The above incentive measures strongly encourage students' learning willingness and innovative thinking.

\section{Epilogue}

The self-learning mode of flash animation course under the open studio mode is a learning mode under the guidance of proposition design project. The introduction of topics and enterprise projects into practical projects will help students improve their academic performance and academic level, provide students with relatively free and open learning space, encourage teachers to guide students to carry out practical projects and innovative project training, so as to organically integrate specialty Industry knowledge and enterprise projects provide incentives.

Author: Zhang Min (1982 -), female, born in Binzhou, Shandong Province, lecturer, mainly engaged in digital media art related research.

Experimental technology project of Binzhou University: Research on self-learning teaching mode of flash animation course under open studio mode, project number: BZXYSYXM201903

\section{Reference}

1. Liu Jingfu, Xie Rongqin. Learning based on "project": Discussion on the application of PBL in enterprise training $[\mathrm{J}]$. China human resource development, 2008 (9)

2. Liu jingfu.pbl: a new model of autonomous learning [J]. Journal of Ningbo University (EDUCATION SCIENCE EDITION), 2007 (10)

3. Wu Jianqiang, Li Yan. Exploration and practice of experimental teaching assessment mode under full open autonomous learning mode [J]. China University teaching, 2011 (4): 70-72

4. Chen Ai Hua, Li Lan, Fu Ge Yan, et al. Exploration of parallel training mode of experimental teaching and innovative education $[\mathrm{J}]$. Laboratory research and exploration, 2004,23 (3): 46

5. He Fen. Discussion on the teaching reform of $2 \mathrm{D}$ 
animation course [J]. Education horizon, 2018, $15: 189$

6. Hao Xianyun. Reform and practice of integration of project-based teaching and doing - based on flash animation course $[\mathrm{J}]$. Institute of curriculum education, 2013, 09:230

7. Lin Chaoping. A preliminary study on the teaching reform of two-dimensional animation course -Taking paperless animation as an example [J]. Popular literature and art (Academic Edition), 2013, (9): 257

8. Wang Zhuli. Systematic learning and fragmented learning [J]. Modern distance education research, 2014 (4): 63

9. Zhang Xu. Preliminary study on teaching reform and research of flash animation design course for animation specialty [J]. Journal of Xinjiang Institute of art, 2011 (2): 116-118

10. Guo Jianlan, Chen Yuqiang, Peng Yong. Research and practice of curriculum reform based on integral system - Taking flash animation production as an example [J]. Journal of Lanzhou Institute of education, 2015 (2): 99 